\title{
Heavy Metal Contamination and Accumulation in Groundwater and Food Crops in Sri Lanka: A Review
}

\author{
A K H Priyashantha ${ }^{1}$, C Mahendranathan ${ }^{2 *}$ \\ ${ }^{1}$ FGS, University of Kelaniya, Sri Lanka \\ ${ }^{2}$ Department of Botany, Eastern University of Sri Lanka. \\ *Email: mjchandrakantha@gmail.com
}

\begin{abstract}
Heavy metal contamination in food crops and ground water lead toxic effects on living organisms through the interference of the metabolic pathways. In this paper, the prevailing scientific data, with regard to the accumulation of heavy metals in groundwater and food crops in Sri Lanka, were reviewed. Evidence revealed that the groundwater bodies in Sri Lanka are in safer level to be used for day-to-day activities with a few exceptions and however, the heavy metal accumulation in some food crops are beyond the permissible level. Chronic Kidney Disease of unknown aetiology is one of the emerging issues at present in dry zones, particularly in the North Central Province in Sri Lanka and its suspected due to the extensive use of agrochemicals which is believed to be contaminated with the heavy metals.
\end{abstract}

Keywords - Agrochemicals, Chronic Kidney Disease of unknown aetiology, Food crops, Groundwater, Heavy metal

\section{INTRODUCTION}

Extensive attention has been paid, during the last two decades to the management of hazardous heavy metals. Heavy metals are the nonbiodegradable, natural components in the earth. It was demonstrated that all the heavy metals contain the toxic impact on living organisms interfering the metabolic pathways. Some heavy metal, however, also acts as microelements (Ali et al., 2013; Jayasumana et al., 2015a).

Toxicity of some of the heavy metals was identified hundreds of years back (e.g. - Lead and arsenic) and that of some others, such as cadmium and beryllium were found more recently (Gwaltney-Brant, 2013). Besides, there are many potential sources of heavy metals such as industrial processes, Mining, Traffic emission, Power plants (coal combustion), commercial products, folk remedies, contaminated food and herbal products (Ali et al., 2013; Jayasumana et al., 2015a; Abeywickrama and Wansapala, 2019). Many heavy metals have been described under the advanced effect on reproduction and development and some are carcinogens (Ali et al., 2013). Heavy metals such as mercury ( $\mathrm{Hg})$, cadmium (Cd), uranium $(\mathrm{U})$, lead $(\mathrm{Pb})$, arsenic (As), antimony $(\mathrm{Sb})$, bismuth $(\mathrm{Bi})$, and plutonium $(\mathrm{Pu})$ are nephrotoxic and while organic forms of lead, arsenic, and mercury cause neurological and reproductive disorders. The gastrointestinal, nervous system and integumentary dysfunction are caused due to the Thallium (Tl) toxicity (Gwaltney-Brant, 2013). Howeveer, level of toxicity is depending on the absorbed dose, the route and the duration of exposure (Jaishankar et al., 2014).

During the last couple of decades, the impacts of heavy metals were discussed widely, because of their hazardous impacts. It has also been reported that the plenitude of heavy metals was discarded as a by-product, due to the emergence of the number of industries (Volesky and Holan, 2003). Groundwater represents $97 \%$ of the world's freshwater and is an important primary source of drinking water in many parts of the world (Mikunthan and De Silva, 2008: Jayasumana et al., 2011). Due to the anthropogenic activities, the groundwater system became polluted particularly, with the As. Mining, fossil fuel burning, use of arsenic fungicides, herbicides and insecticides in agriculture are considered to be the main anthropogenic sources and activities in groundwater contamination, with As (Shankar et al., 2014; Akter and Ali. 2011; Jayawardana et al., 2014). In Chile, Mexico, China, Argentina, the United States, and Hungary and even in the Indian State of West Bengal, Bangladesh and in Vietnam, high level of As in groundwater has been well documented. It was reported that 10 million people in rural areas of India and Bangladesh were threatened as a result of As contamination in their groundwater system (Jayasumana et al., 2011; Yunus et al., 2016). Alam et al., (2003a), also highlighted that millions of people have been affected in Bangladesh due to the use of As-contaminated water from tube wells where contaminated water is being used for drinking, cooking, washing, and irrigation of food crops. Eventually, heavy metals contamination cause health effects through food chain (Wickramaratne et al., 2016; Kananke et al., 2015b; Alkhader, 2015)

On the other hands, contamination of relatively higher-level heavy metals (e.g. - $\mathrm{Cd}, \mathrm{Cu}, \mathrm{Zn}, \mathrm{Pb}, \mathrm{Ni}$ ) have been reported in various food crops such as Abelmoschus esculentus $\mathrm{L}$, Solanum melongena L. Brassica campestris L. Beta vulgari L, Pimpinella anisum L, Cucumis sativus L, Pysum sativum L, Coriandrum Sativum L, Spinacia oleracea L, Lycopersicon esculentum L, Brassica oleracea $\mathrm{L}$ and many more. (Ghosh et al., 2013; Chen et al., 2014; Gupta et al., 2013; Cao et al., 2010; Mubofu, 2012; Alam et al., 2003b; Naser et al., 2009). High levels of As in rice (Oryza sativa $\mathrm{L}$.) have been identified as an important source of inorganic As in the region of South East Asia (Jayasumana et al., 2011).

Chronic Kidney Disease (CKD) is one of the global public health problems at present (Kim et al., 2015). Dissanayake and Chandrajith (2019) stated that in the tropical environments in Sri Lanka, the high evaporation rates of ground water due to 
the effect of climate change, increased the concentrations of many dissolved ions including $\mathrm{F}^{-}, \mathrm{Ca}^{2+}, \mathrm{Na}^{+}, \mathrm{Mg}^{2+}$ and $\mathrm{PO}_{4}{ }^{3-}$ and subsequently it leads to the effect on the health of the people of this these areas, when they consume such water in large quantities.

However, the emergence of a new type of CKD of unknown etiology $(\mathrm{CKDu})$ has faced several health issues, within agricultural community in the country, over the past two decades (Wijewickrama et al., 2019; Cooray et al., 2019).

Research evidence highlighted that CKDu can mainly cause due to the higher intake of heavy metal arsenic (As), cadmium $(\mathrm{Cd})$, and lead $(\mathrm{Pb})$. Sri Lanka has also been reported that increasing number of CKDu patient at an alarming rate mainly due to the use of Agrochemicals such as fertilizers and pesticides (Jayasumana et al., 2013; Kumari et al., 2016; Jayasumana et al., 2014). Moreover, in the past two decades, CKDu has been reported mostly in the dry zonal areas of Sri Lanka's Northern Central Province (NCP) and the northern part of the island, where $45 \%$ of paddy cultivation practices are performed (Espeland, 2016; Athuraliya et al., 2011; Kabata et al., 2016). CKDu is mainly reported in Medawachchiya, Girandurukotte, Kabithigollawa, Padaviya, Medirigiriya, Dehiattakandiya and Nikawewa regions in NCP (Chandrajith et al., 2011). However, Rosemary et al. (2014) indicated that the soil in the dry zone is contaminated with $\mathrm{Cd}$, $\mathrm{Cu}, \mathrm{Pb}, \mathrm{Ni}$, and $\mathrm{Zn}$ but not at a hazardous level.

\section{Heavy Metals Contamination and ACCumulation IN GROUNDWATER, SRI LANKa.}

Sri Lanka's estimated groundwater potential is 780,000hectare meters per annum. Less than $25 \%$ of Sri Lankan households meet their daily water needs through pipelines. However, the majority (about $80 \%$ ) of the population in Sri Lanka obtain drinking water from small, unprotected wells (Mikunthan, and De Silva, 2008).

Groundwater is currently being extensively used for domestic, agricultural and tourism purposes in Sri Lanka. Due to various reasons, the groundwater system in several parts of Sri Lanka is highly affected by the release of wastewater. Contaminated and uncontrolled usage of groundwater leads to develop health risks and limitation to access to the water bodies (Villholth and Rajasooriyar, 2010). Anthropogenic activities include; the application of agrochemicals (pesticides and herbicides), manures and sewage sludge disposal change the natural concentrations of heavy metals at various levels (Sanjeevani et al., 2013).

Heavy metals, such as As, is found in the groundwater system in dry (Eppawala, Talawa, Madirigiriya, Padaviya and Galgamuwa) wet (Hikkaduwa and Kandy) and intermediate (Siyabalangamuwa, Matale, and Naula) zones in Sri Lanka (Fig.1.). However, As accumulation in those areas are below the World Health Organization (WHO) standard for drinking water (Jayawardana et al., 2012). Several studies show that some of the Agrochemicals, used in Sri Lanka contains heavy metals such as $\mathrm{As}, \mathrm{Cd}$ and $\mathrm{Pb}$ (which are highly debated for cause $\mathrm{CKDu}$ in Sri Lanka) and believe to pollute the groundwater system, especially, in the North Central Province (NCP). Wickramarathna et al. (2017) emphasized that Cd, As and $\mathrm{Pb}$ contamination in groundwater and surface water in regions of Uva province Girandurukotte, Nikawewa (NCP) and Central Province (Wilgamuwa), however not exceeded permissible levels (Figure 1.).

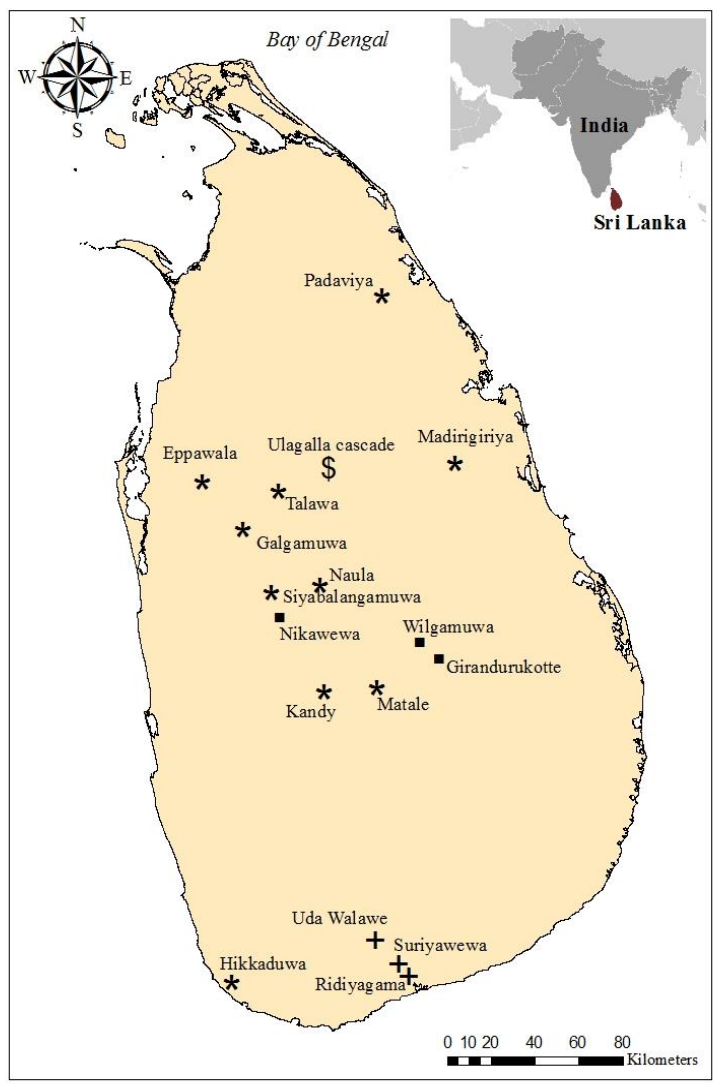

Figure 1. Area, identified as contamination of groundwater with heavy metals. Sources: - - Wickramarathna et al., 2017, ^- Jayawardana et al., 2012, + - Rajasooriyar et al., 2013 and \$ - Wanasinghe et al., 2018)

A study by Wanasinghe et al. (2018) at Ulagalla cascade, Anuradhapura district (North Central Province - NCP) revealed the groundwater system in this area is contaminated with $\mathrm{As}, \mathrm{Pb}$ and $\mathrm{Cd}$ with range of $0.03 \mu \mathrm{g} / \mathrm{L}-0.44 \mu \mathrm{g} / \mathrm{L}$, $1.76 \mu \mathrm{g} / \mathrm{L}-8.85 \mu \mathrm{g} / \mathrm{L}$ and $0.01 \mu \mathrm{g} / \mathrm{L}-0.15 \mu \mathrm{g} / \mathrm{L}$ respectively. However, they further highlighted that concentration of those are below the maximum permissible level of SLS and WHO drinking water quality standards (As and $\mathrm{Pb}-10 \mu \mathrm{g} / \mathrm{L}$ and $\mathrm{Cd}-3 \mu \mathrm{g} / \mathrm{L})$.

Bandara et al. (2008) found that higher levels of heavy metals such as $\mathrm{Cd}, \mathrm{Fe}$ and $\mathrm{Pb}$ contamination in reservoirs in the NCP. They also found that the mean dissolved concentration levels for $\mathrm{Cd}$ (ranged from 0.03 to $0.06 \mathrm{mg} / \mathrm{l}$,) is well above the maximum levels of contamination, recommended by the WHO for drinking water. Furthermore, according to Bandara et al. (2008) mean dissolved concentration level of $\mathrm{Fe}(0.2-1.28 \mathrm{mg} / \mathrm{l})$, $\mathrm{Mn}(0.18 \mathrm{mg} / \mathrm{l})$ and $\mathrm{Pb}(0.01-0.03 \mathrm{mg} / \mathrm{l})$ also showed the higher 
level of mean dissolved concentration, recommended by WHO. Several studies show that farmers have been affected by the widespread use of agrochemicals that lead to more chances for $\mathrm{CKDu}$. The active ingredients of these chemicals may have $\mathrm{Cd}$ plus/or As, and could lead to CKDu (Perera et al., 2016). Furthermore, Malherbe et al., (2018) indicated that the intensive application of agrochemical can also have a significant impact on the groundwater system due to the leaching of such chemicals into the groundwater system. WHO also reported that groundwater is one of the sources to a have CKDu epidemic in Sri Lanka (Wimalawansa, 2014). Wanasinghe et al. (2018) also have highlighted that use of groundwater, contaminated with agrochemicals, leads to the spread of CKDu in NCP.

Rajasooriyar et al. (2013) reported that significant contamination of As in the groundwater system at the southern part of Sri Lanka (Uda Walawe, Suriyawewa and Ridiyagama) and they further reported that the groundwater from deep tube wells shows the range of $0.01-0.04 \mathrm{mg} / \mathrm{L}$ while shallow wells show $0.05-6.1(\mathrm{mg} / \mathrm{L})$.

Inland fisheries of the island are mainly practiced in the NCP (Jinadasa et al., 2013). Study by Allinson et al. (2009) found that Cadmium $(\mathrm{Cd})$, Copper $(\mathrm{Cu})$, Mercury $(\mathrm{Hg})$, Manganese (Mn), and zinc ( $\mathrm{Zn})$ accumulation in Nile tilapia (Oreochromis niloticus L and Oreochromis sp, the most abundance inland fish in Si Lanka), harvested from the freshwater reservoirs such as Kaudulla, Rajanganaya, and Udawalawe reservoirs in Mahaweli, Kala Oya, and Walawe Ganga river basins, respectively. However, they found that the accumulation of heavy metal concentration in the fish body is below the recommended level by WHO and the Food Standards of Australia and New Zealand guideline values. However, Allinson et al. (2009) further indicated that excess intake of such flesh could lead to health risk to the consumers. Jinadasa et al. (2013) highlighted that by consuming contaminated fishes, especially Oreochromis sp. may lead to the incidence of CKDu.

Anthropogenic activities are not only the source of the heavy metal contamination in Sri Lanka but also elevated concentrations of metals released from the ultramafic rocks and their related soils (e.g.- Serpentine soils) are also a source for the heavy metal contamination. These non- anthropogenic sources also release metals into the nearby groundwater systems and leading to ecological, agricultural, and human health-related consequences. The available evidence shows that weathering of ultramafic rocks and serpentinites in Sri Lanka leads to produce a higher amount of $\mathrm{Cr}, \mathrm{Ni}, \mathrm{Co}, \mathrm{Cu}$, Zn, and Mn (Vithanage et al., 2014). As well, they have high potential to release those metals into the local water bodies. Ussangoda, Indikolapelessa, Ginigalpelessa, and Yudhaganawa are some of the areas that have the potential for releasing such metals. Among those, Yudhaganawa recorded the highest $\mathrm{Cr}$ and $\mathrm{Mn}$ concentration and highest $\mathrm{Ni}$ concentration indicated in Ussangoda (Vithanage et al., 2014).

\section{Heavy Metal Contamination AND ACCUMUlation IN FOOD CROPS IN SRI LANKA.}

Some of the recent studies show that the accumulation of heavy metals in food crops in Sri Lanka exceeded the acceptable level. Due to their higher mobility, particularly, heavy metals such as $\mathrm{Cd}$ are more likely to accumulate in plant tissues. In addition, heavy metals such as $\mathrm{Pb}$ are more likely to accumulate in plant roots than the aerial components Kananke, et al., 2015a).

Rice is the staple food crop in Sri Lanka and around 1.8 million farmers are involving in paddy cultivation, island wide. The demand for rice is increasing day by day and in the year 2020 it is expected to reach by $35 \%$ (De Silva et al., 2007; Rajendran et al., 2017). Yet there is a controversy as to whether the high Cd level in the dry zone regions of Sri Lanka is a possible causative factor for CKDu. Chandrajith et al. (2012) revealed that $\mathrm{Cd}$ cannot be a reason for the CKDu in Sri Lanka. They also pointed out that $\mathrm{Cd}$ accumulation in rice in Sri Lanka is below the acceptable level.

By understanding the major impact on human health of glyphosate herbicide, especially in $\mathrm{CKDu}$, the glyphosate was completely banned from the year 2015 . However, a gazette notification lifted the ban on glyphosate for all crops across the country, from July 2018 (http://www.dailymirror.lk, 15.07.2018). Currently, due to the emerging issues in CKDu in Sri Lanka, particularly in North Central Province, the government has launched a project to establish a National Specialized Kidney Hospital in Polonnaruwa (NCP), Sri Lanka (www.president.gov.lk, 10.05.2019).

The study of Jayasumana and co-workers (2015a) indicated that agrochemical glyphosate (a common herbicide - "Roundup") is one of the leading causes of this CKDu and glyphosate is also one of the main contributors to As. Jayasumana et al. (2015b) found that a high proportion of As available in rice as inorganic form. Premarathna et al. (2010) reported that in Sri Lanka, the use of fertilizers in more than recommended doses is a common practice where the intensive vegetable cultivation is carried out. They further mentioned that the presence of heavy metals such as $\mathrm{Cd}, \mathrm{Cu}, \mathrm{Ni}, \mathrm{Pb}$, and $\mathrm{Zn}$ are at elevated levels in agricultural fields (both upcountry and low country wet zone. However, Premarathna et al. (2010) found the concentrations of Cd still below the standard level in vegetable crops.

As per Silva et al. (2016) the heavy metal $(\mathrm{Cu}, \mathrm{Zn} . \mathrm{Pb}, \mathrm{Cd}$, $\mathrm{Cr}$, As) contamination in nine popular vegetable crops, such as carrot (Daucus carota L), beet (Beta vulgaris L), cabbage (Brassica oleracea $\mathrm{L})$, leek (Allium ampeloprasum $\mathrm{L})$, bean (Phaseolus vulgaris $\mathrm{L}$ ), potato (Solanum tuberosum $\mathrm{L}$ ), brinjal (Solanum melongena L), bitter gourd (Momordica charantia $\mathrm{L}$ ) and capsicum (Capsicum annum $\mathrm{L}$ ) contained $\mathrm{Cu}, \mathrm{Zn}, \mathrm{Cd}, \mathrm{Cr}$, and As. However, the accumulation of those heavy metals lower than the maximum permissible level recommended by FAO/WHO (2001). Even though, in the case of potato, the authors reported that the concentration of $\mathrm{Pb}$ is exceeding the mean permissible level, stipulated by FAO/WHO Joint CODEX (2001). 
Kananke et al. (2014) found that presence of heavy metals such as $\mathrm{Ni}, \mathrm{Cd}, \mathrm{Cr}, \mathrm{Pb}$, and $\mathrm{Cu}$ in Sri Lankan common green leafy vegetables such as "Kangkung" (Ipomoea aquatic L), "Mukunuwenna" (Alternanthera sessilis L), "Thampala" (Amaranthus viridis L), "Nivithi" (Basella alba L) and "Kohila" (Lasia spinose L), that were collected from the urban and suburban markets in Piliyandala and Colombo districts of Sri Lanka, given in Table 1.

Table 1: Heavy metal concentration in selected food crops in Sri Lanka.

\begin{tabular}{|c|c|c|c|c|}
\hline \multirow{2}{*}{ Field Samples } & \multicolumn{4}{|c|}{ Range of heavy metal concentration $(\mathrm{mg} / \mathrm{kg})$} \\
\hline & Cd & $\mathbf{C u}$ & $\mathbf{N i}$ & $\mathbf{P b}$ \\
\hline Mukunuwenna & $\begin{array}{l}0.06-0.51 \\
0.07-0.90\end{array}$ & $\begin{array}{c}2.03-33.74 \\
12.64-16.25\end{array}$ & $\begin{array}{l}0.04-26.84 \\
0.79-6.76\end{array}$ & $0.18-1.32$ \\
\hline Nivithi & $\begin{array}{l}0.06-0.62 \\
0.18-0.72\end{array}$ & $\begin{array}{c}1.74-41.62 \\
7.05-13.49\end{array}$ & $\begin{array}{c}0.01-26.87 \\
1.83-6.39\end{array}$ & $0.44-0.97$ \\
\hline Thampala & $\begin{array}{l}0.04-0.55 \\
0.11-0.54\end{array}$ & $\begin{array}{c}2.29-37.63 \\
9.21-12.09\end{array}$ & $\begin{array}{l}0.01-29.16 \\
0.71-3.56\end{array}$ & $0.54-1.09$ \\
\hline Kankung & $\begin{array}{c}0.04-0.71 \\
0.09-0.19\end{array}$ & $\begin{array}{c}4.47-38.84 \\
9.84-13.65\end{array}$ & $\begin{array}{c}0.50-34.22 \\
0.98-15.27\end{array}$ & $0.27-0.45$ \\
\hline Kohila & $\begin{array}{c}0.12-0.88 \\
0.24-0.97^{\mathrm{b}}\end{array}$ & $\begin{array}{c}4.78-45.30 \\
12.87-18.44\end{array}$ & $\begin{array}{c}0.70-38.73 \\
2.45-15.89\end{array}$ & $1.07-1.59$ \\
\hline MPL & 0.2 & 40 & $4^{*}$ & 0.3 \\
\hline
\end{tabular}

Source: (Kananke et al., 2014 and 2016). MPL = maximum permissible limit according to WHO/FAO and * Food and Nutrition Board, Institute of Medicine (2010).

Kananke et al. (2014) further listed these heavy metals in descending order of abundance in green leafy vegetables as $\mathrm{Cu}>\mathrm{Ni}>\mathrm{Cr}>\mathrm{Pb}>\mathrm{Cd}$. The research further highlighted that the contamination level of $\mathrm{Ni}, \mathrm{Cd}, \mathrm{Cr}$, and $\mathrm{Pb}$ have exceeded the maximum permissible limits set by WHO for human consumption. Furthermore, results show that among leafy vegetables, leaves of "Kohila" have the highest tendency to aggregate heavy metals such as $\mathrm{Ni}, \mathrm{Cd}$, and $\mathrm{Cu}$ from the surrounding environment.

The study conducted by Wickramaratne et al. (2016) also indicated that "Kankgkung" (I. aquatic), the roots of "Kohila" (L. spinose), and roots of "Nelum" (Nelumbo nucifera L) are contaminated with heavy metals. They analyzed the samples, collected from different sites of Western Province, (in Kasbewa - suburban area close to Colombo), Southern and North-Central province of Sri Lanka and found that these vegetables are contaminated with the $\mathrm{Zn}, \mathrm{Cu}, \mathrm{Pb}, \mathrm{Ni}$, $\mathrm{Mn}, \mathrm{Hg}, \mathrm{Cr}$, and $\mathrm{Cd}$. They also found that the contamination level of $\mathrm{Cr}$ and $\mathrm{Pb}$ were exceeded the permissible level in these vegetables; Nelum roots, collected from irrigation lakes at Debarawewa (Southern province), Galewela (NCP) and Dambulla (NCP) showed higher content of $\mathrm{Cr}$ and ranged from $2.05-9.23 \mathrm{mg} / \mathrm{kg}$. This level is exceeding the recommended permissible levels of $9.23 \mathrm{mg} / \mathrm{kg}$, imposed by FAO/WHO (1999/2001).
Kananke et al. (2016) pointed out that leafy vegetables growing around the district of Colombo, accumulated with heavy metals, due to the use of contaminated irrigation water and soil. The evidence of elevated heavy metal accumulation and contamination in leafy vegetables, soils and irrigation water in Sri Lanka emphasizing the importance of extensive monitoring and investigations of heavy metal accumulation in soil, water, and edible food to reduce the health risk and environmental pollution (Mahendranathan and Thayaruban, 2018).

\section{CONCLUSION}

Available evidence shows that heavy metal contamination in groundwater and thus in food crops is becoming a major issue with regard to the health concern in Sri Lanka. Hence, reducing the hazardous effect of heavy metals on groundwater systems and food crops by (i) extensive and periodical studies to identify the potential of heavy metal contamination, both qualitatively and quantitatively and (ii) filling the gaps in existing policies to control the extensive use of agrochemicals in agriculture practices are vital in order to prevent the accumulation of heavy metals to the human food chain which subsequently leads to serious health risk in human being in Sri Lanka.

\section{AbBreviations}

As - Arsenic

$\mathrm{Bi}-$ Bismuth

$\mathrm{Ca}^{2+}-$ Calcium ion

$\mathrm{Cd}$ - Cadmium

CKD - Chronic Kidney Disease

$\mathrm{CKDu}$ - Chronic Kidney Disease of unknown aetiology

$\mathrm{Cr}$ - Chromium

$\mathrm{Cu}$ - Copper

$\mathrm{F}^{-}$- Fluoride ion

$\mathrm{Fe}-$ Iron

$\mathrm{Hg}-$ Mercury

$\mathrm{Mg}^{2+}$ - Magnesium ion

Mn - Manganese

$\mathrm{Na}^{+}$- Sodium ion

NCP - Northern Central Province

$\mathrm{Ni}-\mathrm{Nickel}$

$\mathrm{Pb}-$ Lead

$\mathrm{PO}_{4}{ }^{3-}-$ Phosphate ion

$\mathrm{Pu}$ - Plutonium

$\mathrm{Sb}-$ Antimony

$\mathrm{Tl}$ - Thallium

$\mathrm{U}$ - Uranium

$\mathrm{Zn}-$ Zinc 


\section{REFERENCES}

Abeywickrama, C. J. and Wansapala, J. (2019). Review of organic and conventional agricultural products: Heavy metal availability, accumulation and safety. International Journal of Food Science and Nutrition, 4(1): 77-88.

Akter A., and Ali, M. H. (2011). Arsenic contamination in groundwater and its proposed remedial measures. International Journal of Environmental Science and Technology, 8: 433-443.

Alam, M. G. M., Snow, E. T., and Tanaka, A. (2003a). Arsenic and heavy metal contamination of rice, pulses and vegetables grown in Samta village, Bangladesh. In Arsenic Exposure and Health Effects V, 103-114.

Alam, M. G. M., Snow, E. T., and Tanaka, A. (2003b). Arsenic and heavy metal contamination of vegetables grown in Samta village, Bangladesh. Science of the Total Environment, 308(1-3): 83-96.

Ali, H., Khan, E., and Sajad, M. A. (2013). Phytoremediation of heavy metals - Concepts and applications. Chemosphere. 91(7): 869-881.

Alkhader, A. M. F. (2015). The Impact of Phosphorus Fertilizers on Heavy Metals Content of Soils and Vegetables Grown on Selected Farms in Jordan. Agrotechnology, 05(01): 1-5.

Allinson, G., Salzman, S. A., Turoczy, N., Nishikawa, M., Amarasinghe, U. S., Nirbadha, K. G. S., and De Silva, S. S. (2009). Trace metal concentrations in Nile tilapia (Oreochromis niloticus) in three catchments, Sri Lanka. Bulletin of Environmental Contamination and Toxicology, 82(3): 389-94.

Athuraliya, N. T. C., Abeysekera, T. D. J., Amerasinghe, P. H., Kumarasiri, R., Bandara, P., Karunaratne, U, Milton, A.H., and Jones, A. L. (2011). Uncertain etiologies of proteinuricchronic kidney disease in rural Sri Lanka. Kidney International, 80(11): 1212-1221.

Bandara, J. M. R. S., Senevirathna, D. M. A. N., Dasanayake, D. M. R. S. B., Herath, V., Bandara, J. M. R. P., Abeysekara, T., and Rajapaksha, K. H. (2008). Chronic renal failure among farm families in cascade irrigation systems in Sri Lanka associated with elevated dietary cadmium levels in rice and freshwater fish (Tilapia). Environmental Geochemistry and Health, 30(5): 465-478.

Cao, H., Chen, J., Zhang, J., Zhang, H., Qiao, L., and Men, Y. (2010). Heavy metals in rice and garden vegetables and their potential health risks to inhabitants in the vicinity of an industrial zone in Jiangsu, China. Journal of Environmental Sciences, 22(11): 1792-1799.

Chandrajith, R., Ariyaratna, T., and Dissanayake, C. B. (2012). The status of cadmium in the geo-environment of Sri Lanka. Ceylon Journal of Science (Physical Sciences), 16: 47-53.

Chandrajith, R., Nanayakkara, S., Itai, K., Aturaliya, T. N. C., Dissanayake, C. B., Abeysekera, T., Harada, K., Watanabe, T., and Koizumi, A. (2011). Chronic kidney diseases of uncertain etiology (CKDue) in Sri Lanka: Geographic distribution and environmental implications. Environmental Geochemistry and Health, 33(3): 267-278.

Chen, Y., Wu, P., Shao, Y., and Ying, Y. (2014). Health risk assessment of heavy metals in vegetables grown around battery production area. Scientia Agricola, 71(2): 126-132.

Cooray, T., Wei, Y., Zhong, H., Zheng, L., Weragoda, S. K., \& Weerasooriya, A. R. (2019). Assessment of groundwater quality in CKDu affected areas of Sri Lanka: Implications for Drinking Water Treatment. International journal of environmental research and public health, 16(10): 1-16.

Daily Mirror - Sri Lanka Latest Breaking News and Headlines. (2018.July.15). Glyphosate ban lifted. Retrieved from http://www.dailymirror.lk/152720/Glyphosate-ban-lifted

(Accessed on 05. February.2019).

De Silva, C. S., Weatherhead, E. K., Knox, J. W., and Rodriguez-Diaz, J. A. (2007). Predicting the impacts of climate change-A case study of paddy irrigation water requirements in Sri Lanka. Agricultural Water Management, 93(1-2): 19-29.

Dissanayake, C. B., \& Chandrajith, R. (2019). Fluoride and hardness in groundwater of tropical regions - review of recent evidence indicating tissue calcification and calcium phosphate nanoparticle formation in kidney tubules. Ceylon Journal of Science, 48(3): 197-207.

Espeland, M. (2016). Chronic kidney disease (CKD) in Sri Lanka - evaluation of status, practices and potential pollutants. Master's thesis. Norwegian University of Life sciences, Ås.

Ghosh, R., Xalxo, R., and Ghosh, M. (2013). Estimation of heavy metal in vegetables from different market sites of tribal based Ranchi city through Icp-Oes and to Assess health risk. Current World Environment, 8(3): 435-444.

Gupta, S., Jena, V., Jena, S., Davić, N., Matić, N., Radojević, D., and Solanki, J. S. (2013). Assessment of heavy metal contents of green leafy vegetables. Croatian Journal of Food Science and Technology, 5(2): 53-60.

Gwaltney-Brant, S. M. (2013). Heavy Metals. In Haschek and Rousseaux's Handbook of Toxicologic Pathology, 1315-1347.

Jaishankar, M., Tseten, T., Anbalagan, N., Mathew, B. B., and Beeregowda, K. N. (2014). Toxicity, mechanism and health effects of some heavy metals. Interdisciplinary Toxicology, 7(2): $60-72$.

Jayasumana, C., Gunatilake, S., \& Senanayake, P. (2014). Glyphosate, hard water and nephrotoxic metals: Are they the culprits behind the epidemic of chronic kidney disease of unknown etiology in Sri Lanka? International Journal of Environmental Research and Public Health, 11(2): 2125-2147.

Jayasumana, C., Gunatilake, S., and Siribaddana, S. (2015a). Simultaneous exposure to multiple heavy metals and 
glyphosate may contribute to Sri Lankan agricultural nephropathy. BMC Nephrology, 16: 103.

Jayasumana, C., Paranagama, P., Fonseka, S., Amarasinghe, M., Gunatilake, S., and Siribaddana, S. (2015b). Presence of arsenic in Sri Lankan rice. International Journal of Food Contamination, 2(1): 1-5.

Jayasumana, M. A. C. S., Paranagama, P. A., Amarasinghe, M., Fonseka, S. I., and Wijekoon, D. V. K. (2011). Presence of Arsenic in pesticides used in Sri Lanka. In Proceedings of the Water Prof Day Symposium, 127-144. Peradeniya.

Jayasumana, M. A. C. S., Paranagama, P. A, Amarasinghe, M. D., Wijewardane, K. M. R. C., Dahanayake, K.S., Fonseka, S. I., Rajakaruna, K. D. L. M. P., Mahamithawa, A. M. P., Samarasinghe, U. D., and Senanayake, V.K. (2013). Possible link of chronic arsenic toxicity with chronic kidney disease of unknown etiology in Sri Lanka. Journal of Natural sciences research, 3(1): 64-73.

Jayawardana , D. T., Pitawala, H. M. T. G. A., and Ishiga, H. (2014). Assessment of soil geochemistry around some selected agricultural sites of Sri Lanka. Environmental Earth Sciences, 71(9): 4097-4106.

Jayawardana, D. T., Pitawala, H.M.T.G.A., and Ishiga, H. (2012). Geochemical assessment of arsenic and selected trace elements in agricultural and non-agricultural soil in Sri Lanka. Tropical Agriculturist, 160: 1-19.

Jinadasa, B., Subasinghe, M., Thayalan, K., Wickramasinghe, I., and De Silva, M. (2013). Trace Metal contents in muscle tissues of inland fish species in the North central province of Sri Lanka. Ceylon Journal of Science (Biological Sciences), 42(2): 79-86.

Kabata, R., Nanayakkara, S., Senevirathna, S., Harada, K. H., Chandrajith, R., Hitomi, T., Abeysekera, T., Takasuga, T., Koizumi, A. (2016). Neonicotinoid concentrations in urine from chronic kidney disease patients in the north central region of Sri Lanka. Journal of Occupational Health, 58(1): 128-133.

Kananke, T. C., Wansapala, J., and Gunaratne, A. (2015a). Effect of processing methods on heavy metal concentrations in commonly consumed green leafy vegetables available in Sri Lankan market. Pakistan Journal of Nutrition, 14(12): 1026-1033.

Kananke, T. C., Wansapala, J., and Gunaratne, A. (2015b). Pb and $\mathrm{Cr}$ contaminations of irrigation water, soils and green leafy vegetables collected from different areas of Colombo district, Sri Lanka. Pakistan Journal of Nutrition, 14(9): 593-602.

Kananke, T., Wansapala, J., and Gunaratne, A. (2014). Heavy Metal Contamination in Green Leafy vegetables collected from selected market sites of Piliyandala area, Colombo District, Sri Lanka. American Journal of Food Science and Technology, 2(5): 139-144.

Kananke, T., Wansapala, J., and Gunaratne, A. (2016). Detection of $\mathrm{Ni}, \mathrm{Cd}$, and $\mathrm{Cu}$ in green leafy vegetables collected from different cultivation areas in and around Colombo
District, Sri Lanka. Environmental Monitoring and Assessment, 188(3): 1-12.

Kim, N. H., Hyun, Y. Y., Lee, K. B., Chang, Y., Rhu, S., Oh, K. H., and Ahn, C. (2015). Environmental heavy metal exposure and chronic kidney disease in the general population. Journal of Korean Medical Science, 30(3): 272-277.

Kumari, M. K. N., Rathnayake, R. M. C.P., Kendaragama, K. M. A., Gunarathna, M. H. J. P., and Nirmanee, K. G. S. (2016). Drinking water quality in chronic kidney disease of unknown aetiology $(\mathrm{CKDu})$ prevalent and non-prevalent areas in Giradurukotte, Sri Lanka, International Journal of Advances in Agricultural and Environmental Engineering, 3(1): 57-60.

Mahendranathan C., and Thayaruban, T, (2018). Evidences of Heavy Metal Contamination and Their Consequences in Sri Lanka with special reference to agriculture: A Review. International Journal of Research in Agriculture and Forestry, 5(8): 14-20.

Malherbe, H., Gebel, M., Pauleit, S., and Lorz., C. (2018). Land Use Pollution Potential of Water Sources Along the Southern Coast of South Africa. Change and Adaptation in Socio-Ecological Systems, 4(1): 7-20.

Mikunthan, T., and De Silva, C.S.(2008). Vulnerability Assessment for Shallow Aquifers Using Chemical Quality of Groundwater: A Case Study from Thirunelvely and Kondavilin Jaffna District. Tropical Agricultural Research, 20: 303-312.

MoU signed for Polonnaruwa Kidney Hospital (2017). Retrieved from http://www.president.gov.lk/mou-signed-forpolonnaruwa-kidney-hospital (Accessed on 10. May. 2019).

Mubofu, E. B. (2012). Heavy metal content in some commonly consumed vegetables from Kariakoo market, Dar- es -Salaam, Tanzania. Tanzania Journal of Science, 38(3): 201-208.

Naser, H.M., Shil, N. C., Mahmud, N. U., Rashid, M. H., and Hossain, K. M. (2009). Lead, Cadmium and Nickel Contents of Vegetables Grown in Industrially Polluted and Nonpolluted Areas of Bangladesh. Bangladesh Journal of Agricultural Research, 34(4): 545-554.

Perera, P. C. T., Sundarabarathy, T. V., Sivananthawerl, T., Kodithuwakku, S. P., and Edirisinghe, U. (2016). Arsenic and Cadmium Contamination in Water, Sediments and Fish is a Consequence of Paddy Cultivation: Evidence of River Pollution in Sri Lanka. Achievements in the Life Sciences, 10(2): 144-160.

Premarathna, H. M. P. L., Hettiarachchi, G. M., and Indraratne, S. P. (2010). Trace Metal Concentration in Crops and Soils Collected from Intensively Cultivated Areas of Sri Lanka. Pedologist, 54(3): 230-240.

Rajasooriyar, L. D., Boelee, E., Prado, M. C. C. M., and Hiscock, K. M. (2013). Mapping the potential human health implications of groundwater pollution in southern Sri Lanka. Water Resources and Rural Development, 1-2: 27-42. 
Rajendran, M., Gunawardena, E. R. N., and Dayawansa., N. D. K. (2017). Impacts of Climate Change on Irrigation Water Demand of Paddy: A case study from Hakwatuna oya irrigation scheme in Sri Lanka. Tropical Agricultural Research, 28 (4): 375-388.

Rosemary, F., Vitharana, U. W. A., Indraratne, S. P., and Weerasooriya, S. V. R. (2014). Concentrations of trace metals in selected land uses of a dry zone soil catena of Sri Lanka. Tropical Agricultural Research, 25(4): 412-422.

Sanjeevani, U. K. P. S., Indraratne, S. P., Weerasooriya, S. V. R., and Vitharana, U. W. A. (2013). Baseline values of cadmium and zinc in three land uses in a selected mapping unit of the dry zone of Sri Lanka. Tropical Agricultural Research, 25(1): $84-95$.

Shankar, S., Shanker, U., and Shikha. (2014). Arsenic contamination of groundwater: A review of sources, prevalence, health risks, and strategies for mitigation. Scientific World Journal, 2014: 1-18.

Silva, N. R. N., Weerasinghe, P. and Rathnapriya, H. D. K. (2016). Toxic trace elements in vegetables collected from markets in Kandy district. Tropical Agriculturist, 164: 57-69.

Villholth, K. G., and Rajasooriyar, L. D. (2010). Groundwater resources and management challenges in Sri Lanka-an overview. Water Resources Management, 24(8): 1489-1513.

Vithanage, M., Rajapaksha, A. U., Oze, C., Rajakaruna, N., and Dissanayake, C. B. (2014). Metal release from serpentinesoils in Sri Lanka. Environmental Monitoring and Assessment, 186(6): 3415-3429.

Volesky, B., and Holan, Z. R. (2003). Biosorption of heavy metals. American Chemical Society and American Institute of Chemical Engineers, 11(3): 235-250.
Wanasinghe, W. C. S., Gunarathna., M. H. J. P., Herath, H. M. P. I. K., and Jayasinghe, G. Y. (2018). Drinking Water Quality on Chronic Kidney Disease of Unknown Aetiology (CKDu) in Ulagalla Cascade, Sri Lanka. Sabaragamuwa University Journal, 16(1): 17-27.

Wickramarathna, S., Balasooriya, S., Diyabalanage, S., and Chandrajith, R. (2017). Tracing environmental aetiological factors of chronic kidney diseases in the dry zone of Sri LankaA hydrogeochemical and isotope approach. Journal of Trace Elements in Medicine and Biology, 44: 298-306.

Wickramaratne, M. N., Maduranga, T. M., and Chamara, L. L. S. (2016). Contamination of heavy metals in aquatic vegetables collected from cultivation sites in Sri Lanka. IOSR Journal of Environmental Science, Toxicology and Food Technology (IOSRJESTFT), 10(11): 76-82.

Wijewickrama, E. S., Gunawardena, N., Jayasinghe, S., and Herath, C. (2019). CKD of unknown etiology (CKDu) in Sri Lanka: A multilevel clinical case definition for surveillance and epidemiological studies. Kidney International Reports, 4(6): 781-785.

Wimalawansa, S. A., and Wimalawansa, S. J. (2014). Impact of changing agricultural practices on human health: Chronic kidney disease of multi-factorial origin in Sri Lanka. Wudpecker Journal of Agricultural Research, 3 (5): 110-124.

Yunus, F. M., Khan, S., Chowdhury, P., Milton, A. H., Hussain, S., and Rahman, M. (2016). A Review of groundwater arsenic contamination in Bangladesh: The millennium development goal era and beyond. International Journal of Environmental Research and Public Health, 13(2): 215 . 
